\title{
QUALITY PRESERVATION OF 'LAETITIA' PLUMS IN ACTIVE MODIFIED ATMOSPHERE STORAGE ${ }^{1}$
}

\author{
MAYARA CRISTIANA STANGER ${ }^{2}$, CRISTIANO ANDRÉ STEFFENS ${ }^{3}$, \\ CASSANDRO VIDAL TALAMINI DO AMARANTE ${ }^{4}$, AURI BRACKMANN $^{5}$, \\ ROGÉRIO OLIVEIRA ANESE ${ }^{6}$
}

ABSTRACT- Recent studies have shown that passive modified atmosphere storage (MA) delays the ripening of 'Laetitia' plums but it increases the incidence of internal browning in comparison to cold storage (CS), possibly due to high $\mathrm{CO}_{2}$ and/or ethylene accumulation inside the package. The aim of this study was to evaluate the effect of active MA conditions [LDPE film $(40 \mu \mathrm{m})$ ] with $\mathrm{CO}_{2}$ absorber combined with low ethylene (LE) on ripening and quality preservation of 'Laetitia' plums during storage at $0.5^{\circ} \mathrm{C} \pm 0.1^{\circ} \mathrm{C}$ and $\mathrm{RH}$ of $96 \% \pm 2 \%$. The treatments evaluated were cold storage (CS; $21.0 \mathrm{kPa} \mathrm{O}+<0.03 \mathrm{kPa} \mathrm{CO}_{2}$ ); nonperforated $\mathrm{MA}$ with $\mathrm{CO}_{2}$ absorber; non-perforated $\mathrm{MA}$ with $\mathrm{CO}_{2}$ absorber and LE; perforated MA (with two perforations with diameter $=0.5 \mathrm{~mm}$ ) with $\mathrm{CO}_{2}$ absorber; and perforated $\mathrm{MA}$ with $\mathrm{CO}_{2}$ absorber and LE. The partial pressures of $\mathrm{O}_{2}+\mathrm{CO}_{2}(\mathrm{kPa})$ were $1.2+<0.1$ and $2.8+<0.1$, in non-perforated and perforated MA, respectively. Active MA, mainly non-perforated package, with $\mathrm{CO}_{2}$ absorber and LE, delayed fruit ripening, but did not reduce the incidence of internal breakdown in 'Laetitia' plums cold stored for 60 days. Fruits in active MA, with perforated or non-perforated package, with $\mathrm{CO}_{2}$ absorber and LE, showed lower intensity of internal breakdown than CS.

Index terms: Prunus salicina, internal breakdown, ethylene, postharvest, ripening.

\section{MANUTENÇÃO DA QUALIDADE DE AMEIXAS 'LAETITIA' ARMAZENADAS EM ATMOSFETA MODIFICADA ATIVA}

RESUMO - Trabalhos recentes têm demonstrado que a atmosfera modificada (AM) passiva retarda o
amadurecimento de ameixas 'Laetitia', mas causa maior ocorrência de escurecimento da polpa do que o
armazenamento refrigerado (AR), possivelmente devido ao acúmulo de $\mathrm{CO}_{2}$ e/ou ao etileno no interior da
embalagem. O objetivo deste trabalho foi avaliar o efeito da $\mathrm{AM}$ ativa, com absorção de $\mathrm{CO}_{2}$, combinada
com baixo etileno (BE) sobre o amadurecimento e a manutenção da qualidade de ameixas 'Laetitia' durante
o armazenamento a $0,5^{\circ} \mathrm{C} \pm 0,1^{\circ} \mathrm{C}$ e UR de $96 \% \pm 2 \%$. Os tratamentos avaliados foram: AR $\left(21 \mathrm{kPa}\right.$ de $\mathrm{O}_{2}+$
$0,03 \mathrm{kPa}$ de $\left.\mathrm{CO}_{2}\right) ; \mathrm{AM}+$ absorvedor de $\mathrm{CO}_{2} ; \mathrm{AM}+$ absorvedor de $\mathrm{CO}_{2}$ e $\mathrm{BE} ; \mathrm{AM}$ com perfuração (duas
perfurações de $0,5 \mathrm{~mm}$ de diâmetro) + absorvedor de $\mathrm{CO}_{2} ; \mathrm{AM}$ com perfuração + absorvedor de $\mathrm{CO} 2 \mathrm{e}$ BE. Nos
tratamentos com AM, foi utilizado o filme de polietileno de baixa densidade de $40 \mu \mathrm{m}$. As pressões parciais
médias de $\mathrm{O}_{2}+\mathrm{CO}_{2}(\mathrm{kPa}$ ) foram $2,8+<0,1$ e $1,2+<0,1$, em $\mathrm{AM}$ com perfuração e AM sem perfuração,
respectivamente. A AM ativa, especialmente em embalagem não perfurada, com absorvedor de $\mathrm{CO}_{2}$ e BE
$\left(<0,04 \mu \mathrm{L} \mathrm{L}^{-1}\right)$, retardou o amadurecimento dos frutos, mas não reduziu a incidência de escurecimento da
polpa após 60 dias de armazenamento. Os frutos acondicionados em AM ativa, em embalagem com ou sem
perfuração, com absorvedor de $\mathrm{CO}_{2}$ e BE, apresentaram menor intensidade de escurecimento da polpa do
que em AR.

Termos para indexação: Prunus salicina, escurecimento de polpa, etileno, pós-colheita, amadurecimento.

1(Paper 235-15). Received on September 29, 2015. Accepted April 12, 2016.

${ }^{2} \mathrm{PhD}$ student in Plant Production, Postgraduate Program in Plant Production, CAV/UDESC. Av. Luiz de Camões, 2090, CEP 88520000, Lages-SC, Brasil. E-mail: mayara.stanger@gmail.com

${ }^{3}$ Dr., CNPQ Research Productivity Scholarship, Full Professor of the Department of Agronomy, CAV/UDESC. Av. Luiz de Camões, 2090, CEP 88520-000, Lages-SC, Brasil. E-mail: cristiano.steffens@udesc.br. Author for correspondence.

${ }^{4}$ Ph.D., CNPQ Research Productivity Scholarship, Full Professor of the Department of Agronomy, CAV/UDESC. Av. Luiz de Camões, 2090, CEP 88520-000, Lages-SC, Brasil. E-mail: cassandro.amarante@udesc.br.

${ }^{5}$ Dr., CNPQ Research Productivity Scholarship, Associate Professor, Department of Plant Science, CCR/UFSM. Av. Roraima, 1000, CEP 97105-900, Santa Maria-RS, Brasil. E-mail: auri@brackmann.com.br.

${ }^{6} \mathrm{PhD}$ student in Agronomy, Postgraduate Program in Agronomy, CCR/UFSM. Av. Roraima, 1000, CEP 97105-900, Santa Maria-RS, Brasil. E-mail: rogerio_anese@yahoo.com.br 


\section{INTRODUCTION}

'Laetitia' plums show rapid ripening and a reduced postharvest life, the storage period being limited by the rapid loss of flesh firmness and internal browning (SINGH; SINGH, 2013a; STEFFENS et al., 2014).

The internal browning is a disturbance that affects plums stored under refrigeration, being considered damage by cold (SINGH et al., 2009; SINGH; SINGH, 2013b). The internal browning due to an oxidative process related to the production of reactive oxygen species has been proposed, which cause lipid peroxidation and the reduction in the efficiency of antioxidant systems, with consequent damage to cell membranes (SINGH; SINGH, 2012; 2013a; 2013b). In addition, internal browning may be aggravated by the action of the ethylene (CANDAN et al., 2008; 2011), as well as by a reduction of the energy metabolism, implying a lower energy supply for the maintenance of cell membranes (SAQUET et al., 2003). Storage conditions with excessive $\mathrm{O}_{2}$ reduction or $\mathrm{CO}_{2}$ increase raise the incidence and severity of internal browning (SINGH; SINGH, 2013a, STEFFENS et al., 2014), as they compromise the antioxidant system (SINGH; SINGH, 2013a).

The storage in modified atmosphere (MA) associated with the temperature reduction has allowed some fruits to be stored for longer and with better quality maintenance (ALI et al., 2004) because it is a storage system that causes greater reduction in the cellular metabolism than the isolated use of the refrigeration (STEFFENS et al., 2007a).The temperature reduction, the decrease of the partial $\mathrm{O}_{2}$ pressure and the increase of the partial $\mathrm{CO}_{2}$ pressure through the MA are the main factors that contribute to the maintenance of the product quality and, consequently, the reduction of post-harvest losses (STEFFENS et al., 2007a). Thus, the MA could increase the supply period of the 'Laetitia' plum, as well as enable the commercialization of better quality fruits during the off season.

Although MA contributes to the maintenance of fruit quality, it may in some cases induce fermentation and the development of physiological disturbances in fruits, due to the intense reduction in $\mathrm{O}_{2}$ levels and increase of $\mathrm{CO}_{2}$ (STEFFENS et al., 2007b). 'Laetitia' plums stored for 60 days in MA, where $\mathrm{CO}_{2}$ accumulation occurred between 9.6 and $16 \mathrm{kPa}$, although this condition delayed fruit maturation, there was an increase in the incidence of internal browning (STEFFENS et al., 2009). However, MA conditions without $\mathrm{CO}_{2}$ accumulation can be promising because controlled atmosphere conditions with low $\mathrm{O}_{2}$ and $\mathrm{CO}_{2}$ levels (up to $1 \mathrm{kPa}$ ) provided the best results for maintaining the quality of 'Laetitia' plums (STEFFENS et al., 2014). In this way, the use of $\mathrm{CO}_{2}$ absorber inside the MA storage would be an alternative to reduce the partial pressure of this gas in the package and could delay the ripening of 'Laetitia' plums, without increasing the incidence and/or severity of internal browning.

Several studies have demonstrated the effect of 1-methylcyclopropene (1-MCP), an ethylene action inhibitor, on ripening delay and control of plum internal browning (ARGENTA et al., 2003; CANDAN et al., 2006; 2011; CORREAA et al., 2011). However, the 1-MCP has a high cost and a difficult application management to be implemented in MA storage. Thus, the addition of ethylene absorber within the MA package may represent an alternative to minimize the ethylene effects, and thereby delay the ripening that occurs during prolonged periods of cold storage and to prevent physiological disorders.

The aim of this study was to evaluate the effect of active MA, with $\mathrm{CO}_{2}$ absorber and low ethylene, on ripening and maintenance of postharvest quality of 'Laetitia' plums.

\section{MATERIALS AND METHODS}

The 'Laetitia' plums were harvested in a nine-year-old commercial orchard, conducted in a "Y" system, located in the municipality of LagesSC (27 $48^{\prime} 58^{\prime \prime} \mathrm{S}$ and 50 $\left.19^{\prime} 34^{\prime \prime} \mathrm{W}\right)$, and after being transported to the laboratory of Postharvest Physiology and Technology of the Agroveterinary Sciences Center of the State University of Santa Catarina. In the laboratory, the fruits were selected; eliminating those with lesions, defects or mechanical damages, and later the homogenization of the experimental units was carried out.

The experimental design was completely randomized, with four replicates per treatment and experimental unit composed of 30 fruits. The treatments used were: cold storage $\left(\mathrm{CS} ; 21 \mathrm{kPa}\right.$ of $\mathrm{O}_{2}$ $+0.03 \mathrm{kPa}$ of $\left.\mathrm{CO}_{2}\right), \mathrm{MA}+\mathrm{CO}_{2}$ absorber; $\mathrm{MA}+\mathrm{CO}_{2}$ absorber and low ethylene (LE); perforated MA + $\mathrm{CO}_{2}$ absorber; perforated $\mathrm{MA}+\mathrm{CO}_{2}$ absorber and $\mathrm{LE}$. In the MA treatments, the low-density polyethylene film of $40 \mu \mathrm{m}$ was used, and a sachet containing hydrated lime $\left(50 \mathrm{~g} \mathrm{~kg}^{-1}\right.$ of fruit) was placed inside the package to absorb $\mathrm{CO}_{2}$. In the perforated MA treatment, two perforations of $0.5 \mathrm{~mm}$ diameter were carried out in the middle region of the package. In the treatments with LE, the chemical absorption of this gas inside the package was carried out through the addition of sachets (a sachet of $10 \mathrm{~g}$ for every three 
kilos of fruits) containing pellets with $\mathrm{KMnO}_{4}$. The fruits of all treatments were stored for 60 days in a cold room at a temperature of $0.5^{\circ} \mathrm{C} \pm 0.1^{\circ} \mathrm{C}$ and $\mathrm{RH}$ of $96 \% \pm 2 \%$.

During storage, the partial pressures of $\mathrm{O}_{2}$ and $\mathrm{CO}_{2}$ were monitored weekly, using an Agridatalog gas analyzer.

After 60 days of storage, the samples were divided into two sub-samples of 15 fruits, one for analysis at the exit of the chamber and another for analysis after three days of shelf life $\left(20 \pm 2^{\circ} \mathrm{C} / 60 \pm 5 \%\right.$ of RH). The variables analyzed were flesh firmness, texture attributes (forces to peel rupture, flesh penetration and fruit compression), red color index (RCI), color of the epidermis $\left(h^{\circ}\right)$, intensity of internal browning (L), occurrence of cracking, rot and internal browning, respiratory and ethylene production rates, titratable acidity (TA) and soluble solids (SS), according to the methodology described in Corrêa et al. (2011) and Steffens et al. (2014).

The data were submitted to analysis of variance and the averages of the treatments were compared by the Tukey test $(\mathrm{p}<0.05)$, with the SAS program. The percentage data, before being submitted to ANOVA, were transformed by the $\operatorname{arcsen}[(\mathrm{x}+0.5) / 100]^{1 / 2}$.

\section{RESULTS AND DISCUSSION}

The average atmospheric composition was $1.2 \mathrm{kPa}$ of $\mathrm{O}_{2}+<0.1 \mathrm{kPa} \mathrm{CO}_{2}$ and $2.8 \mathrm{kPa}$ of $\mathrm{O}_{2}+$ $<0.1 \mathrm{kPa}$ of $\mathrm{CO}_{2}$ for MA without and with perforated package, respectively. The average concentration of ethylene in the treatments during storage was $5.22 \mu \mathrm{L} \mathrm{L}^{-1}$ in $\mathrm{CS}, 2.77 \mu \mathrm{L} \mathrm{L}^{-1}$ in MA treatments without ethylene absorption, and $<0.04 \mu \mathrm{L} \mathrm{L}^{-1}$, in MA treatments with LE.

After three days of fruit exposure under ambient conditions, all fruits in MA had lower ethylene production rates than CS fruits (Table 1).The MAP, due to the respiratory process of the fruits and the diffusion barrier of the gases, reduced the partial pressure of $\mathrm{O}_{2}$ during storage, reducing the oxidation of the ACC (1-aminocyclopropane1-carboxylic acid) to ethylene (BLANKENSHIP; DOLE, 2003), and the effect of the low $\mathrm{O}_{2}$ storage on the reduction of ethylene production may persist during the period of exposure to the ambient condition (BRACKMANN et al., 2015).

The respiratory rate, at the exit of the chamber, was lower in fruits in MA with perforated packages plus the use of $\mathrm{CO}_{2}$ and $\mathrm{LE}$ absorbers and in MA without perforated package and with $\mathrm{CO}_{2}$ absorber, independent of the ethylene absorption (Table 1).This result shows that in MA with perforated package, the modification of the atmosphere, in terms of $\mathrm{O}_{2}$ reduction, was less intense, providing higher ethylene production in these fruits, since $\mathrm{O}_{2}$ is required for the oxidation of ACC to ethylene by the enzyme ACC oxidase. After three days under ambient conditions, the respiratory rate was lower in fruits in MA with non-perforated package, plus $\mathrm{CO}_{2}$ and LE absorber (Table 1), but without differing from MA treatment with non-perforated and $\mathrm{CO}_{2}$ absorber package. Probably, the respiratory rate of the fruit was reduced by the low partial pressures of $\mathrm{O}_{2}$ inside the nonperforated package (BRACKMANN et al., 2006), and this effect persisted during the fruit exposure period under ambient conditions.

The fruits of all MA treatments showed a lower red color index and lower intensity (higher $h^{\circ}$ ) of red color in both evaluations than those maintained in CS. The MA treatments, on the other hand, showed differences between them only in the three days of shelf life, where the fruits in MA with package without perforation and with $\mathrm{CO}_{2}$ absorber showed lower value of red color index and higher $h^{\circ}$ (Table 1). Under MA conditions, there was a reduction in the partial pressures of $\mathrm{O}_{2}$, which should have exerted greater control in the biosynthesis and ethylene action and, consequently, on the evolution of the fruits color, especially in the fruits in MA with packages without perforation. The color maintenance of the epidermis should be related to the lower biosynthesis and ethylene action in MA (JAYAS; JEYAMKONDAN, 2002), because the color change during the ripening of plums is a process dependent on the action of this phytohormone (ARGENTA et al., 2003; CANDAN et al., 2006; CANDAN et al., 2011).

After 60 days of storage plus three days at ambient conditions, flesh firmness and texture attributes (forces to epidermis rupture, flesh penetration and fruit compression) were higher in fruits in MA with non-perforated package and with $\mathrm{CO}_{2}$ absorber, independent of ethylene (Table 2). The flesh firmness considered one of the attributes of greater importance in fruits quality, since it influences the fruit crunchiness and affects the resistance to the transport and the attack of microorganisms (JAYAS; JEYAMKONDAN, 2002; JERONIMO et al., 2007). The fruit softening, after color change, is the most evident transformation occurring during the plums ripening. The reduction of the partial pressure of $\mathrm{O}_{2}$ acts inhibiting glycolysis, the cycle of tricarboxylic acids and the respiratory chain (SAQUET et al., 2003), besides reducing ethylene biosynthesis, causing less degradation of the cell wall by the action of hydrolytic enzymes that are dependent on this 
phytohormone (ALI et al., 2004; CIA et al., 2006).

In this study, no LE effect was observed on the maintenance of flesh firmness and forces for peeling rupture and fruit compression. However, for the force to penetrate the flesh, the LE maintained a higher value (Table 2). During the ripening of the fruits, an increase in the activity of the pectinamylesterase and polygalacturonase enzymes occurs and the middle lamella disintegration occurs, processes influenced by the ethylene action, with consequent softening of the fruits (KHAN; SINGH, 2007; CANDAN et al., 2011). Although the flesh firmness and the flesh penetration force are related variables, there was a slightly different behavior among them. This is due to the fact that in the evaluation of flesh firmness, the resistance of the epidermis and the hypodermic tissue are disregarded (GUILLERMIN et al., 2006). Steffens et al. (2013) observed similar behavior in 'Laetitia' plums stored under controlled atmosphere.

The TA was higher in fruits in MA with nonperforated package and with $\mathrm{CO}_{2}$ and $\mathrm{LE}$ absorber, after 60 days of storage and three days of exposure at ambient conditions, than in fruits kept in CS (Table $3)$. The organic acids are substrates of the respiratory process and may be less degraded due to the reduction in respiratory rate under MA and LE conditions (CIA et al., 2006).

The incidence of cracked fruits at the exit of the chamber was lower in MA treatment in nonperforated packages with $\mathrm{CO}_{2}$ and $\mathrm{LE}$ absorber than in CS and MA treatments in perforated package and with $\mathrm{CO}_{2}$ absorber (Table 3). However, there was no difference between treatments after three days shelf life (data not shown). In the 'Laetitia' plums, stored under controlled atmosphere, the low $\mathrm{O}_{2}$ reduced the occurrence of cracks, compared to CS (STEFFENS et al., 2014), corroborating with the results of this study, and a higher occurrence of this disorder is possibly related to excessive fruit ripening.

All treatments showed 100\% incidence of internal browning after three days in ambient conditions (Table 3). However, in spite of the fact that all the treatments had a high incidence of internal browning, the fruits kept in MA with $\mathrm{CO}_{2}$ absorber and LE, regardless of whether the package was perforated or not, showed lower internal browning intensity ( $L$ - pulp color), after three days of shelf life. The internal browning, although it is a coldinduced disorder, is aggravated by the action of ethylene (ARGENTA et al., 2003; CANDAN et al., 2008; CANDAN et al., 2011), corroborating with the results of this study.

The SS, after 60 days of storage and three days of fruit exposition at ambient conditions, and the incidence of rot, both at the exit of the chamber and after three days of fruits exposure at ambient conditions, showed no differences between treatments (data not shown).

The results show that the use of active MA, in package with or without perforation, with $\mathrm{CO}_{2}$ absorber and LE, reduced the intensity, but not the incidence of internal browning, after 60 days of storage at $0.5^{\circ} \mathrm{C}$. This seems to show that, for 'Laetitia' plums, the refrigerated storage period should be less than 60 days. This justifies additional studies aiming to evaluate the potential of using active MA, with $\mathrm{CO}_{2}$ and $\mathrm{LE}$ absorber, in ripening and internal browning control for periods of less than 60 days. 
TABLE 1- Ethylene and respiratory rates and epidermis color of 'Laetitia' plums stored under different atmospheres for 60 days $\left(0.5^{\circ} \mathrm{C} \pm 0.2^{\circ} \mathrm{C} / 92 \pm 2 \%\right.$ of relative humidity) at the exit of the chamber and after three days of shelf life $\left(20 \pm 2^{\circ} \mathrm{C} / 60 \pm 5 \%\right.$ of relative humidity).

\begin{tabular}{|c|c|c|c|c|}
\hline \multirow[b]{2}{*}{ Storage conditions } & \multirow{2}{*}{$\begin{array}{c}\text { Ethylene production } \\
\text { rate } \\
\left(\mathrm{pmol} \mathrm{kg}^{-1} \mathrm{~s}^{-1}\right)\end{array}$} & \multirow{2}{*}{$\begin{array}{c}\text { Respiratory rate } \\
\left(\mu \mathrm{mol} \mathrm{CO}_{2} \mathrm{~kg}^{-1} \mathrm{~s}^{-1}\right)\end{array}$} & \multicolumn{2}{|c|}{ Epidermis color } \\
\hline & & & $\begin{array}{c}\mathrm{RCI} \\
(1-4)^{* * * *}\end{array}$ & ${ }^{o} h$ \\
\hline \multicolumn{5}{|c|}{ Chamber exit } \\
\hline $\mathrm{CS}^{*}$ & - & $403.8 \mathrm{a}$ & $3.4 \mathrm{a}$ & $51.9 \mathrm{~b}$ \\
\hline $\mathrm{MA}^{* *+}+$ perforation & - & $401.7 \mathrm{a}$ & $2.9 \mathrm{~b}$ & $71.2 \mathrm{a}$ \\
\hline $\mathrm{MA}+$ perforation $+\mathrm{LE}^{* * *}$ & - & $337.8 b$ & $2.9 \mathrm{~b}$ & $68.7 \mathrm{a}$ \\
\hline MA & - & $308.6 \mathrm{~b}$ & $2.5 b$ & $76.3 \mathrm{a}$ \\
\hline $\mathrm{MA}+\mathrm{LE}$ & - & $339.0 \mathrm{~b}$ & $2.7 b$ & $73.9 \mathrm{a}$ \\
\hline CV $(\%)$ & - & 4.17 & 8.02 & 5.96 \\
\hline \multicolumn{5}{|c|}{ After three days of shelf life } \\
\hline $\mathrm{CS}$ & $4.2 \mathrm{a}$ & $527.0 \mathrm{a}$ & $3.8 \mathrm{a}$ & $40.2 \mathrm{c}$ \\
\hline $\mathrm{MA}+$ perforation & $0.2 b$ & $501.6 \mathrm{a}$ & $3.3 \mathrm{ab}$ & $64.7 \mathrm{ab}$ \\
\hline $\mathrm{MA}+$ perforation $+\mathrm{LE}$ & $0.1 b$ & $493.7 \mathrm{a}$ & $3.6 \mathrm{a}$ & $57.6 \mathrm{~b}$ \\
\hline MA & $0.5 b$ & $468.7 \mathrm{ab}$ & $2.9 \mathrm{~b}$ & $73.3 \mathrm{a}$ \\
\hline $\mathrm{MA}+\mathrm{LE}$ & $0.2 b$ & $385.4 \mathrm{~b}$ & $3.5 \mathrm{ab}$ & $67.1 \mathrm{ab}$ \\
\hline $\mathrm{CV}(\%)$ & 44.08 & 8.92 & 7.63 & 11.78 \\
\hline
\end{tabular}

$* \mathrm{CS}$ : cold storage $\left(21 \mathrm{kPa}\right.$ of $\mathrm{O}_{2}+0.03 \mathrm{kPa}$ of $\left.\mathrm{CO}_{2}\right)$; **MA: modified atmosphere with $\mathrm{CO}_{2}$ absorber; ***LE: low ethylene; **** RCI: red color index ( $1-0-25 \% ; 2-26-50 \% ; 3-51-75 \%$ and $4-76-100 \%$ with red pigmented fruit surface). Averages in the columns followed by the same letter do not differ from each other by Tukey test $(\mathrm{p}<0.05)$.

TABLE 2- Flesh firmness and texture attributes (forces for peel rupture, flesh penetration and fruit compression) in 'Laetitia' plums stored under different atmospheres for 60 days $\left(0.5^{\circ} \mathrm{C} \pm\right.$ $0.2^{\circ} \mathrm{C} / 92 \pm 2 \%$ of relative humidity) followed by more three days of shelf life $\left(20 \pm 2^{\circ} \mathrm{C} / 60 \pm 5 \%\right.$ of relative humidity).

\begin{tabular}{lcccc}
\hline Storage conditions & $\begin{array}{c}\text { Flesh } \\
\text { firmness (N) }\end{array}$ & $\begin{array}{c}\text { Force for } \\
\text { peel } \\
\text { rupture }(\mathrm{N})\end{array}$ & $\begin{array}{c}\text { Force for } \\
\text { flesh } \\
\text { penetration (N) }\end{array}$ & $\begin{array}{c}\text { Force for } \\
\text { fruit compression (N) }\end{array}$ \\
\hline CS* $^{*}$ & $19.0 \mathrm{~b}$ & $4.3 \mathrm{c}$ & $0.8 \mathrm{c}$ & $15.4 \mathrm{~b}$ \\
$\mathrm{MA}^{* *}+$ perforation & $17.5 \mathrm{~b}$ & $5.2 \mathrm{~b}$ & $0.8 \mathrm{c}$ & $15.2 \mathrm{~b}$ \\
$\mathrm{MA}+$ perforation + LE*** & $18.1 \mathrm{~b}$ & $5.5 \mathrm{~b}$ & $0.9 \mathrm{c}$ & $15.7 \mathrm{~b}$ \\
$\mathrm{MA}$ & $22.4 \mathrm{a}$ & $7.3 \mathrm{a}$ & $1.1 \mathrm{~b}$ & $20.9 \mathrm{a}$ \\
$\mathrm{MA}+\mathrm{LE}$ & $24.1 \mathrm{a}$ & $7.2 \mathrm{a}$ & $1.3 \mathrm{a}$ & $22.2 \mathrm{a}$ \\
$\mathrm{CV}(\%)$ & 14.2 & 6.3 & 6.2 & 5.7 \\
\hline
\end{tabular}

$* \mathrm{CS}$ : cold storage $(21 \mathrm{kPa}$ of $\mathrm{O} 2+0.03 \mathrm{kPa}$ of $\mathrm{CO} 2)$; * MA: modified atmosphere with $\mathrm{CO}_{2}$ absorber; ***LE: low ethylene. Averages in the columns followed by the same letter do not differ from each other by Tukey test $(\mathrm{p}<0.05)$. 
TABLE 3- Incidence of cracks, at the exit of the chamber, and titratable acidity, incidence and intensity of internal browning (pulp color measured by color attribute $L$ ), after three days shelf life $\left(20 \pm 2^{\circ} \mathrm{C} / 60 \pm 5 \%\right.$ of relative humidity) in 'Laetitia' plums stored under different atmospheres for 60 days $\left(0.5^{\circ} \mathrm{C} \pm 0.2^{\circ} \mathrm{C} / 92 \pm 2 \%\right.$ of relative humidity).

\begin{tabular}{lcccc}
\hline Storage conditions & Cracks $(\%)$ & $\begin{array}{c}\text { Titratable acidity } \\
\left(\mathrm{meq} 100 \mathrm{~mL}^{-1}\right)\end{array}$ & $\begin{array}{c}\text { Internal browning } \\
(\%)\end{array}$ & Pulp color $(L)$ \\
\hline CS* & $24.4 \mathrm{a}$ & $5.9 \mathrm{~b}$ & 100 & $41.3 \mathrm{bc}$ \\
MA**+ perforation & $29.6 \mathrm{a}$ & $6.2 \mathrm{ab}$ & 100 & $39.5 \mathrm{c}$ \\
MA + perforation + LE*** & $13.3 \mathrm{ab}$ & $7.3 \mathrm{ab}$ & 100 & $48.7 \mathrm{a}$ \\
MA & $13.4 \mathrm{ab}$ & $6.3 \mathrm{ab}$ & 100 & $45.4 \mathrm{ab}$ \\
MA + LE & $4.4 \mathrm{~b}$ & $8.2 \mathrm{a}$ & 100 & $48.1 \mathrm{a}$ \\
CV $(\%)$ & 27.6 & 13.9 & - & 7.5 \\
\hline
\end{tabular}

*CS: cold storage $(21 \mathrm{kPa}$ of $\mathrm{O} 2+0.03 \mathrm{kPa}$ of CO2); **MA: modified atmosphere with $\mathrm{CO} 2$ absorber; ***LE: low ethylene. Averages in the columns followed by the same letter do not differ from each other by Tukey test $(\mathrm{p}<0.05)$.

\section{CONCLUSION}

The active modified atmosphere, especially in non-perforated package with $\mathrm{CO}_{2}$ absorber and low ethylene, delays ripening of fruits and reduces the intensity of internal browning, although it has no effect on the incidence of internal browning in 'Laetitia' plums stored for 60 days at $0.5^{\circ} \mathrm{C}$.

\section{ACKNOWLEDGEMENT}

The authors thank the National Council for Scientific and Technological Development (CNPq) and the Foundation for Research and Innovation Support of the State of Santa Catarina (FAPESC) for the financial support for this project.

\section{REFERENCES}

ALI, Z.M.; CHIN, L., MARIMUTHU, M.; LAZAN, H. Low temperature storage and modified atmosphere packaging of carambola fruit and their effects on ripening related texture changes, wall modification and chilling injury symptoms. Postharvest Biology and Technology, Amsterdam, v.33, n.2, p.181-92, 2004.

ARGENTA, L.C.; KRAMMES, J.G.; MEGGUER, C.A.; AMARANTE, C.V.T.; MATTHEIS, J. Ripening and quality of 'Laetitia' plums following harvest and cold storage as affected by inhibition of ethylene action. Pesquisa Agropecuária Brasileira, Brasília, DF, v.38, n.10, p.1139-48, 2003.
B L A N KEN SH IP, S.M.; DOLE, J.M. 1-Methylcyclopropene: a review. Postharvest Biology Technology, Amsterdam, v.28, n.1, p.125, 2003.

BRACKMANN, A.; GIEHL, R.F.H.; FREITAS, S.T.; EISERMANN, A.C.; MELLO, A.M. Uso de filmes de polietileno e absorção de etileno para o transporte refrigerado de maçã 'Gala'. Ciência Agrária, Londrina, v.27, n.3, p.423-8, 2006.

BRACKMANN, A.; WEBER, A.; BOTH, V. $\mathrm{CO}_{2}$ partial pressure for respiratory quotient and harvest watch dynamic controlled atmosphere for 'Galaxy' apples storage. Acta Horticulturae, The Hague, n.1079, p.435-40, 2015.

CANDAN, A.P.; GRAEL, J.; CRISOSTO, C.; LARRIGAUDIÉRE, C. Improvement of storability and shef-life of 'Blackamber' plums treated with 1-methylcyclopropene. Food Science and Technology International, Valência, v.12, n.2, p.437-43, 2006.

CANDAN, A.P.; GRAEL, J.; LARRIGAUDIÉRE, C. Postharvest quality and chilling injury of plums: benefits of 1-methylcyclopropene. Spanish Journal of Agricultural Research, Madrid, v.9, n.2, p.55464, 2011.

CANDAN, A.P.; GRAELL. J.; LARRIGAUDIÉRE, C. Roles of climacteric ethylene in the development of chilling injury in plums. Postharvest Biology and Technology, Amsterdam, v.47, n.1, p.107-12, 2008. 
CIA, P.; BENATO, E.A.; SIGRIST, J.M.M.; SARANTOPÓULOS, C.; OLIVEIRA, L.M.; PADULA, M. Modified atmosphere packaging for extending the storage life of 'Fuyu' persimmon. Postharvest Biology and Technology, Amsterdam, v.42, n.3, p.228-34, 2006.

CORREAA, T.R.; STEFFENS, C.A.; TANAKA, H.; AMARANTE, C.V.T.; BRACKMANN, A.; ANESE, R.O. Ameixas 'Laetitia' armazenadas em atmosferas controlada e modificada ativa com manejo do etileno. Revista Brasileira de Fruticultura, Jaboticabal, v.33, n.3, p.723-9, 2011.

GUILLERMIN, P.; DUPONT, N.; LE MORVAN, C.; LE QUÉRÉ, J.M.; LANGLAIS, C.; MAUGET, J.C. Rheological and technological properties of two cider apple cultivars. LWT - Food Science and Technology, Georgia, v.39, n.9, p.995-1000, 2006.

JAYAS, D.S.; JEYAMKONDAN, S. Modified atmosphere storage of grains meats fruits and vegetables. Biosystems Engineering, Amsterdam, v.82, n.3, p.235-51, 2002.

JERONIMO, M.E.; BRUNINI, M.A.; ARRUDA, M.C.; CRUZ, J.C.S.; FISCHER, I.H.; GAVA, G.J.C. Conservação pós-colheita de mangas 'Tommy Atkins' armazenadas sob atmosfera modificada. Semina: Ciências Agrárias, Londrina, v.28, n.3, p.417-26, 2007.

KHAN, A.S.; SINGH Z. 1-MCP regulates ethylene biosynthesis and fruit softening during ripening of 'Tegan Blue' plum. Postharvest Biology and Technology, Amsterdam, v.43, n.3, p.298-306, 2007.

SAQUET, A. A.; STREIF, Josef; BANGERTH, Fritz . Energy metabolism and membrane lipid alterations related to the incidence of brown heart in Conference pears during delayed controlled atmosphere storage. Postharvest Biology and Technology, Amsterdam, v.30, n.2, p.123-132, 2003

SINGH, S.P., SINGH, Z.; SWINNY, E.E. Postharvest nitric oxide fumigation delays fruit ripening and alleviates chilling injury during cold storage of Japanese plums (Prunus salicina Lindell). Postharvest Biology and Technology, Amsterdam, v.53, n.3, p.101-8, 2009.
SINGH, S.P.; SINGH, Z. Controlled and modified atmospheres influence chilling injury, fruit quality and antioxidative system of japanese plums (Prunus salicina Lindell). International Journal of Food Science and Technology, Christchurch, v.48, n.2, p.363-74, 2013a.

SINGH, S.P.; SINGH, Z. Postharvest cold storageinduced oxidative stress in Japanese plums (Prunus salicina Lindl. cv. Amber Jewel) in relation to harvest maturity. Australian Journal of Crop Science, Lindfield, v.7, n.3, p.391-400, 2013b.

SINGH, S.P.; SINGH, Z. Role of membrane lipid peroxidation, enzymatic and non-enzymatic antioxidative systems in the development of chilling injury in japanese plums. Journal of the American Society for Horticultural Science, Alexandria, v.137, n.6, p.473-81, 2012.

STEFFENS, C.A.; AMARANTE, C.V.T.; ALVES, E.O.; BRACKMANN, A. Fruit quality preservation of 'Laetitia' plums under controlled atmosphere storage. Annals of the Brazilian Academy of Sciences, Rio de Janeiro, v.86, n.1, p.485-94, 2014.

STEFFENS, C.A.; AMARANTE, C.V.T.; ALVES, E.O.; TANAKA, H.; BRACKMANN, A.; BOTH, V. Armazenamento de ameixas 'Laetitia' em atmosfera modificada. Ciência Rural, Santa Maria, v.39, n.9, p.2439-44, 2009.

STEFFENS, C.A.; BRACKMANN, A.; LOPES, S.J.; PINTO, J.A.V.; EISERMANN, A.C.; GIEHL, R.F.H.; WEBBER, A. Degenerescência da polpa e respiração de quivi cv. Bruno em função das condições de armazenamento. Ciência Rural, Santa Maria, v.37, n.6, p.1621-6, 2007b.

STEFFENS, C.A.; BRACKMANN, A.; PINTO, J.A.V.; EISERMANN, A.C. Taxa respiratória de frutas de clima temperado. Pesquisa Agropecuária Brasileira, Brasília, DF, v.42, n.3, p.313-21, 2007a.

STEFFENS, C.A.; TANAKA, H.; AMARANTE, C.V.T.; BRACKMANN, A.; STANGER, M.C.; HENDGES, M.V. Condições de atmosfera controlada para armazenamento de ameixas 'Laetitia' tratadas com 1-metilciclopropeno. Revista Ciência Agronômica, Fortaleza, v.44, n.4, p.750-6, 2013. 